УДК 640.4:005.2]:[005.61:658.261

DOI: $10.31866 / 2616-7468.4 .2 .2021 .249079$

\section{УПРАВЛІННЯ ГОТЕЛЬНО- РЕСТОРАННИМ КОМПЛЕКСОМ НА ЗАСАДАХ ЕНЕРГОЕФЕКТИВНОСТІ}

Оксана Миколюк,

доктор економічних наук,

Хмельницький національний університет

Хмельницький, Україна, oksanamik81@gmail.com https://orcid.org/0000-0001-8526-0829

(C) Миколюк О., 2021

Актуальність. Сталий розвиток підприємств готельно-ресторанного господарства (ГРГ) неможливий без надійного, стабільного, обгрунтованого забезпечення енергетичними ресурсами. Основні потенційні можливості для розвитку галузі досі не реалізовані. Економічні труднощі, зростання вартості енергії, жорстка конкуренція між учасниками висувають нові вимоги до якості та ефективності готельно-ресторанного господарства. Ось чому стає все більш важливим забезпечення відповідної конкурентоспроможності вітчизняних готелів і підприємств ресторанного господарства на основі енергоефективності. Раціональне та ощадливе споживання енергетичних ресурсів визначає енергоефективність їх функціонування та відіграє провідну роль у забезпеченні економічного зростання вітчизняних підприємств сфери послуг. Пріоритетом у розвитку підприємств сфери гостинності дедалі частіше стають стабільне функціонування та зростання економічного потенціалу в умовах ринкових відносин, що головним чином залежать від наявності системи енергоефективності. Предметом дослідження $є$ формування стратегії енергоефективності, що сприятиме координації дій вищого менеджменту у розв’язанні проблем забезпечення енергоефективного функціонування готельно-ресторанного комплексу. Мета дослідження полягає у теоретико-методологічному обгрунтуванні значення та місця системи енергоефективності в системі стратегічного управління готельно-ресторанного комплексу. Методи дослідження: монографічний аналіз, абстрагування та морфологічний аналіз, групування і класифікації. Головні результати і висновки. В результаті дослідження розкрито сутність та послідовність етапів управління енергоефективністю готельно-ресторанного комплексу. Сформовано взаємозв'язки стратегії енергоефективності готельно-ресторанного комплексу та механізму ї̈ управління. Запропоновано алгоритм розробки стратегії енергоефективності готельно-ресторанного комплексу та обгрунтовано її складові.

Ключові слова: управління, готельно-ресторанний комплекс, енергоефективність, стратегія енергоефектиності. 


\section{Актуальність проблеми}

Постановка проблеми. В умовах сучасної економічної глобалізації на індустрію готелів і підприємств ресторанного господарства впливають зовнішні та внутрішні зміни, що спонукає вищий менеджмент до пошуку стратегій, інструментів і способів управління, що засновані на системному та інтегрованому методах, з урахуванням факторів енергоефективності. Для розвитку готельного господарства України все більшого значення набуває енергозбереження і процес формування нових бізнес-форматів та управлінських структур. В умовах посилення конкурентної боротьби, обмеженості економічних і вичерпності енергетичних ресурсів зростає актуальність грунтовного аналізу функціонування соціальноекономічних систем, у тому числі і закладів готельно-ресторанного господарства. 3 цією метою менеджмент готельно-ресторанного бізнесу зосереджує зусилля на аналізі поточного стану і перспектив розвитку готельно-ресторанних комплексів у напрямах уточнення та коригування стратегії розвитку, посилення конкурентних переваг, зміцнення ділової репутації, збільшення економічного потенціалу, підвищення ефективності функціонування системи управління, зростання показників енергоефективності виробництва продукції та надання послуг, формування мотиваційного середовища на основі енергоощадності, забезпечення корпоративної культури та ін.

У цьому контексті енергоефективність $є$ необхідною умовою існування і розвитку як держави в цілому, так і окремої соціально-економічної одиниці. Енергоефективність готельно-ресторанного комплексу покликана убезпечити від різного роду небезпек та загроз, пов'язаних із перебоями постачання паливноенергетичних ресурсів, їх оптимальних обсягів, якості та своєчасності, що головним чином впливає на виробничий та обслуговуючий процес.

Стан вивчення проблеми. Необхідною умовою функціонування готельно-ресторанного комплексу $є$ наявність можливостей для попередження ризиків шляхом прийняття раціональних і ефективних управлінських рішень щодо захисту інтересів підприємства та недопущення збитків, ефективність і результативність яких визначає рівень їх енергоефективності. Вирішення таких завдань потребує чіткого уявлення щодо функціонування готельно-ресторанних комплексів, основних показників їх діяльності, які пов'язані із процесами енергоефективності.

Слід зауважити, що питання управління енергоефективністю на всіх рівнях ієрархії були і залишаються об’єктом дослідження багатьох учених, серед яких можна виділити таких, як: А. Амоша, В. Федоренко та Н. Белопольский (2008), Є. Бобров (2013), В. Геєць, М. Кизим та Т. Клебанова (2006), 3. Варналій, Д. Буркальцева та О. Саєнко (2011), О. Кузьмін, Н. Подольчак та В. Матвї̈шин (2011). Заслуговують на увагу наукові дослідження В. Соколової, Г. Крусір, Т. Шпирко, І. Кузнєцової та І. Коваленко (2019), Г. Ряшко, Г. Крусір та Т. Новічкової (2016), Н. Валінкевич (2018), Н. Кузнєцової та С. Нездоймінова (2010), С. Галасюк та О. Шикіної (2015) та ін. Проте, незважаючи на зростаючий інтерес науковців до проблеми управління енергоефективністю підприємств індустрії гостинності, відмітимо, що і до сьогодні немає належного рішення стосовно деяких аспектів діяльності підприємств щодо формування конкретних управлінських рішень із забезпечення їх сталого розвитку 
на засадах енергоефективності. На наше переконання, фактор енергоефективності та формування механізму управління енергоефективністю повинні враховуватись при підготовці і прийнятті рішень щодо напрямів соціально-економічного розвитку сфери гостинності та при розробці заходів виходу із кризового стану в умовах сьогодення.

Невирішені питання. Для вирішення проблеми енергетичної ефективності готельно-ресторанного комплексу ключовим питанням $є$ впровадження стратегії, яка сприятиме координації дій вищого менеджменту підприємств у розв'язанні проблем зниження енергоємності продукції та послуг. Проблема забезпечення енергоефективності підприємств сфери гостинності пов'язана із посиленням енергетичної залежності України від інших країн, обмеженістю в енергетичних ресурсах, а також стрімким зростанням їх вартості. Це мотивує до пошуку нових методів та інструментів у визначенні шляхів зниження обсягів використання енергетичних ресурсів, їх ефективного і раціонального споживання.

\section{Мета і методи дослідження}

Meта статmі - формування базису управління готельно-ресторанним комплексом на засадах енергоефективної спрямованості. У роботі досліджено проблеми енергетичної ефективності, вирішення яких передбачає розробку відповідної стратегії та механізму з метою формування системи управління енергоефективністю готельно-ресторанного комплексу.

Методологічною основою дослідження є як загальнонаукові, так і спеціальні методи економічної теорії, наукові роботи вітчизняних і зарубіжних вчених щодо розвитку готельно-ресторанного комплексу та управління його енергоефективністю.

Об'єкт дослідження - процеси управління енергоефективністю готельно-ресторанним комплексом.

Предмет дослідження - формування стратегії енергоефективності, що сприятиме координації дій вищого менеджменту у розв’язанні проблем забезпечення енергоефективного функціонування готельно-ресторанного комплексу.

Наукова новизна полягає в обгрунтуванні впровадження стратегії енергоефективності, яка сприятиме координації дій вищого менеджменту готельно-ресторанного комплексу у розв’язанні проблем зниження енергоємності продукції та послуг.

Методи дослідження: монографічний аналіз - для дослідження енергоефективності як загальнонаукової категорії; абстрагування та морфологічний аналіз - для впорядкування категоріального апарату та узгодження із напрямом дослідження; групування і класифікації - для дослідження факторів, чинників і загроз енергоефективності готельно-ресторанного комплексу.

Інформаційна база дослідження: монографії, наукові статті, матеріали міжнародних конференцій.

\section{Результати дослідження}

Ефективність управління готельно-ресторанним комплексом значною мірою визначається формуванням його цілісної системи управління, що слугує підгрунтям для розв'язання основних завдань управлінської діяльності. Неподіль- 
ність та цілісність такої системи управління є необхідною умовою забезпечення життєздатності підприємств у ринковій економіці, а формування у її складі системи управління енергоефективністю слід розглядати як сукупність взаємозв'язаних елементів, що взаємодіють із зовнішнім середовищем як неподільне ціле. Враховуючи умови формування системи управління енергоефективністю готельно-ресторанного підприємства, зауважимо щодо необхідності побудови сучасного механізму управління процесом забезпечення енергоефективного розвитку, що передбачає налагодження координації діяльності підприємств із метою досягнення економічної та соціальної ефективності використання ними енергетичних ресурсів.

Формування концепції управління енергоефективністю готельно-ресторанного комплексу слід розглядати крізь призму системи поглядів, вимог та умов реалізації заходів щодо забезпечення його безпеки. Звідси концепція управління енергоефективністю підприємства грунтується на чітко сформованих системах організації управління економічним розвитком, враховуючи забезпечення енергетичними ресурсами належної якості.

О. Г. Череп зазначає, що створення та реалізація концепції відбувається від самого початку заснування підприємства та у подальшому процесі виробничо-господарської діяльності. Ефективність впровадженої концепції оцінюють за показниками якісного і своєчасного забезпечення зростання економічного розвитку готельно-ресторанного підприємства та обсягу власних ресурсів, впровадження в роботу інноваційного технічного облаштування, забезпечення фінансової стійкості та конкурентоспроможності. До концепції ефективного управління енергоефективністю готельно-ресторанного підприємства також входить комплекс методів організації, управління та запобігання небезпекам і загрозам (Єрмаченко \& Журавльова, 2015; Завідна, 2017).

Таким чином, концепція управління енергоефективністю готельно-ресторанного комплексу повинна містити наступну послідовність етапів: аналіз ризиків та загроз управлінню енергоефективністю підприємства; розробку методологічного інструментарію оцінки стану управління енергоефективністю підприємства; розробку стратегії управління енергоефективністю готельно-ресторанного комплексу; розробку механізму управління енергоефективністю готельно-ресторанного комплексу; оцінку ефективності управління енергоефективністю готельно-ресторанного комплексу; коригування тактики та стратегії управління енергоефективністю відповідно до зміни умов (рис. 1).

Виконання першого етапу полягає у діагностуванні енергоефективності готельно-ресторанного комплексу, що передбачає виявлення можливих та реальних загроз, небезпек, ранжування їх за ступенем важливості; виявлення причин їх виникнення, подальше прогнозування ймовірних наслідків їх реалізації, а також формулювання проблемних ситуацій у сфері енергоефективності.

На другому етапі відбувається розробка методологічного інструментарію оцінки енергоефективності готельно-ресторанного комплексу, до складу якого входять: вибір методів оцінки, визначення основних критеріїв і показників стану енергоефективності підприємства, а також рівня енергоефективності.

Метою третього етапу управління енергоефективністю готельно-ресторанного комплексу є розробка стратегії управління енергоефективністю, підгрунтям якої слугує оцінка енергоефективності готельно-ресторанного комплексу, здійс- 


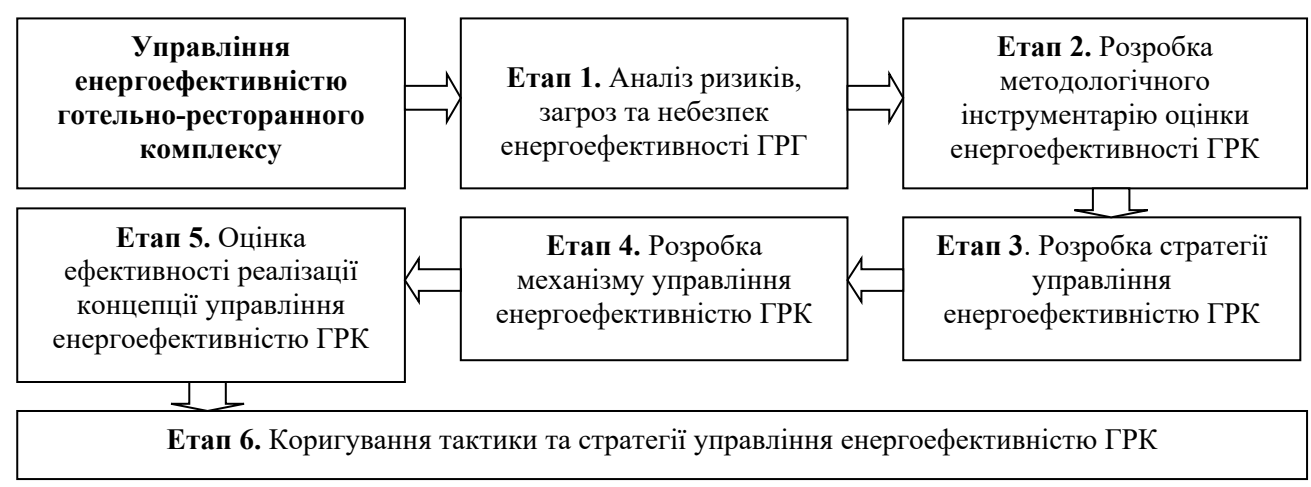

Puc. 1. Схема управління енергоефективністю готельно-ресторанного підприємства

Fig. 1. Scheme of energy efficiency management of hotel and restaurant enterprise

нена в рамках другого етапу реалізації концепції. Зауважимо, на цьому етапі визначаються конкретні цілі щодо забезпечення енергоефективності, мета управління нею з урахуванням проблемних ситуацій, а також здійснюється постановка завдань, що сприятимуть досягненню мети концепції управління енергоефективністю та реалізації стратегії управління енергоефективністю готельно-ресторанного комплексу.

Четвертий етап полягає у розробці тактики управління енергоефективністю готельно-ресторанного комплексу. Метою цього етапу є вибір принципів енергоефективності готельно-ресторанного комплексу, визначення функцій управління енергоефективністю, вибір організаційної структури управління енергоефективністю підприємства. Важливість розробки тактики управління енергоефективністю готельно-ресторанного комплексу забезпечується необхідністю розробки комплексу заходів реалізації основних положень його концепції, що потребує створення необхідних умов для реалізації процесу управління енергоефективністю готельно-ресторанного комплексу; пошук джерел ресурсного забезпечення концепції управління енергоефективністю; підготовку кваліфікованого персоналу у сфері управління енергоефективністю; створення підрозділу енергоефективності та організація управління ним; встановлення технічних засобів захисту; контроль за ефективністю виконання основних положень концепції енергоефективності; розвиток системи енергоефективності готельно-ресторанного підприємства та удосконалення форм і методів управління.

Окрім цього, цей етап передбачає розробку механізму управління енергоефективністю готельно-ресторанного комплексу, який є основою його концепції та визначає послідовність дій у її забезпеченні. Кінцевою метою реалізації концепції управління енергоефективністю готельно-ресторанного комплексу є безпосереднє створення такого дійового механізму управління енергоефективністю. Оцінка ефективності реалізації концепції управління енергоефективністю готельноресторанного комплексу має на меті зіставлення відповідності концепції сформульованим у ній цілям та завданням, а також оцінку ефективності реалізованої концепції управління енергоефективністю готельно-ресторанного комплексу.

Заключним етапом запровадження концепції управління енергоефективністю готельно-ресторанного комплексу є етап коригування тактики, стратегії 
управління енергоефективністю, визначення засобів досягнення цілей, враховуючи зміни у внутрішньому та зовнішньому середовищах.

Отже, основним етапом формування концепції управління енергоефективністю готельно-ресторанного комплексу є побудова його ефективного механізму, який би був орієнтований на своєчасне виявлення та запобігання зовнішнім і внутрішнім загрозам та забезпечення захисту його інтересів.

На сьогодні виокремлено три підходи до управління будь-якими процесами, в тому числі й енергоефективністю, а саме: функціональний, динамічний та предметний (за об’єктами управління) (Барановська та ін., 2019; Завідна, 2017). Управління енергоефективністю на засадах функціонального підходу передбачає реалізацію основних функцій управління через часткові функції. Управління на засадах динамічного підходу передбачає розгляд усіх процесів відповідно до часу їх реалізації. Управління при цьому здійснюється за конкретними етапами, обумовлюється поступовим виконанням робіт згідно із розробленим проєктом (починаючи з ідеї, підготовки конкретного проєкту, закінчуючи здачею об'єкта в експлуатацію). Одним із можливих варіантів реалізації проєктів за такого підходу є побудова алгоритму, в якому виділено всі етапи для деталізації виконуваних робіт. Предметний підхід в управлінні визначає об'єкти безпосереднього управління, тобто безпосередні об’єкти, потужності, ресурси (інформаційні, фінансові, матеріальні, кадрові, енергетичні тощо); види діяльності, яка безпосередньо пов’язана і з управлінням енергоефективністю, і $з$ досягненням запланованих економічних та соціальних результатів (Миколюк, 2019).

Отже, аналізуючи зазначені підходи через призму управління всією енергоефективністю, а не лише її окремо взятими проєктами, можемо зробити висновок, що лише функціональний підхід дозволяє забезпечити цілісність управлінської діяльності, а динамічний та предметний підходи є здебільшого прив'язаними до окремого проєкту.

Оскільки управління енергоефективністю належить до одного із пріоритетних напрямів стратегічного управління готельно-ресторанним підприємством, то варто зосередити увагу саме на функціональному підході, який повинен базуватися на п'яти основних функціях: плануванні, організації, мотивуванні, контролі та регулюванні. Зауважимо, що необхідно застосовувати всі без винятку зазначені функції, оскільки нехтування хоча б однією з них призведе до зниження рівня дієвості управління енергоефективністю.

3 огляду на вказане відмітимо, що в сьогоднішніх умовах поточної української кризи важливим і першочерговим завданням $€$ досягнення оптимального рівня енергоефективності готельно-ресторанного комплексу завдяки ефективному функціонуванню механізму її забезпечення, що є визначальним за таких обставин. Основними передумовами формування механізму забезпечення енергоефективності є визначення стратегії енергоефективності та тактичних заходів iï реалізації, обгрунтування системи найважливіших показників за спорідненими ознаками, відстеження зовнішніх та внутрішніх загроз в енергоефективній сфері (Завідна, 2017). Механізм забезпечення енергоефективності повинен бути комплексним та таким, що забезпечує функціонування системи енергоефективності держави. Оптимальним поєднанням є злагоджена система функціонування трьох основних механізмів: організаційно-економічного, правового та інституційного. 
Організаційно-економічний механізм забезпечення енергоефективності слід розглядати як сукупність інституційних, організаційних структур і комплекс використовуваних ними економічних законів, закономірностей та форм і методів нівелювання й усунення внутрішніх і зовнішніх загроз у сфері енергоефективності. До цього механізму входитимуть економічні, адміністративні, фінансові, законодавчо-нормативні форми, важелі, стимули і методи регулювання та модель інноваційного розвитку системи енергоефективності (Берзіна та ін., 2017; Бобров, 2013; Валінкевич, 2018, Варналій та ін., 2011; Галасюк \& Шикіна, 2015; Геєць та ін., 2006).

Аналіз ряду наукових робіт (Амоша та ін., 2008; Барановська та ін., 2019; Берзіна та ін., 2017; Бобров, 2013; Валінкевич, 2018; Варналій та ін., 2011; Галасюк \& Шикіна, 2015; Геєць та ін., 2006; Єрмаченко \& Журавльова, 2015) показав, що основні завдання механізму управління енергоефективністю готельно-ресторанного комплексу (ГРК) мають тісний зв'язок зі стратегічними інтересами самого підприємства (рис. 2).

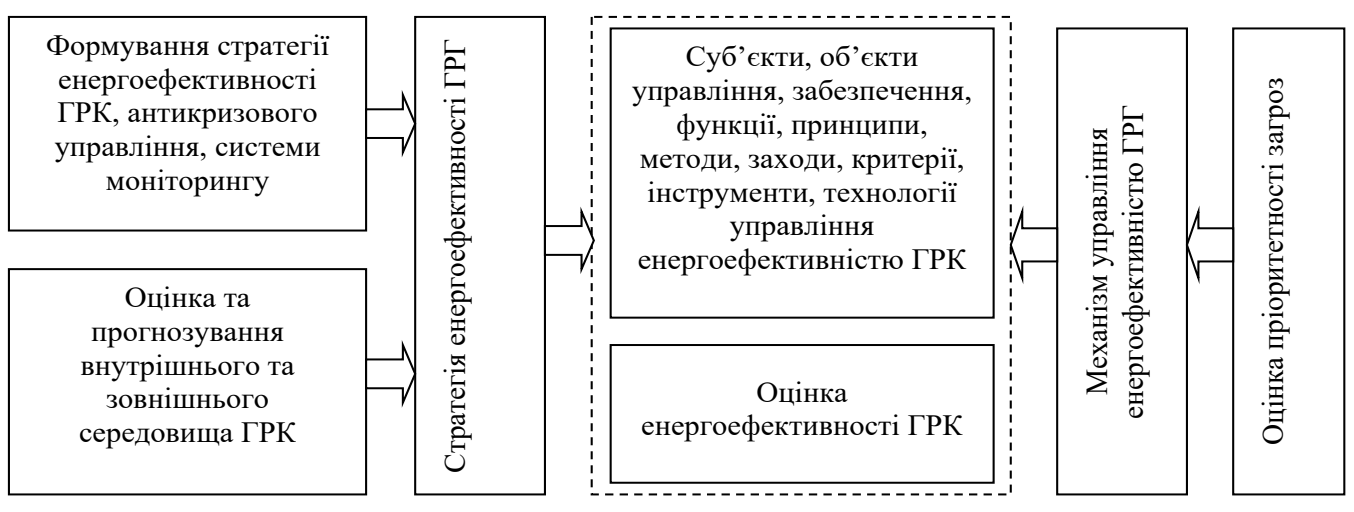

Puc. 2. Взаємозв’язок стратегії енергоефективності готельно-ресторанного комплексу та механізму її управління

Fig. 2. The correlation between the energy efficiency strategy of the hotel and restaurant complex, and the mechanism of its management

Вважаємо, що стратегія енергоефективності має бути базою та стратегією вищого рівня для формування стратегії енергозбереження ГРК. Така ієрархічність слугуватиме забезпеченню принципів міжнародного стандарту ISO 50001:2011 «Energy management systems - Requirements with guidance for use», що встановлює вимоги до системи енергетичного менеджменту, на основі яких організація може розробити і впровадити енергетичну політику, здійснити постановку цілей та завдань і розробити плани дій з урахуванням законодавчих вимог та даних про значне використання енергії (Рижик та ін., 2020, Романів та ін., 2015, Ряшко та ін., 2016).

Ознайомившись із дослідженнями фахівців та використавши власні напрацювання, вважаємо, що стратегія енергоефективності ГРК формується під впливом ряду чинників, які умовно можна поділити на зовнішні (макро- та мікрооточення підприємства) і внутрішні. 
Макрооточення готельно-ресторанного комплексу визначає загальні умови, в яких повинна формуватися його стратегія енергоефективності, i характеризується політичними, правовими, економічними, соціальними, технологічними, природними і науково-технічними факторами. До чинників мікросередовища включають вимоги споживачів до продукції, політику енергозбереження конкурентів, умови постачання енергоресурсів та енергозберігаючого обладнання. До внутрішніх чинників формування стратегії енергоефективності ГРК слід віднести концепцію розвитку підприємства, його стратегічні цілі, визначені загальною корпоративною стратегією, а також стратегічний потенціал підприємства (ресурсо-сировинний, виробничий, трудовий, інвестиційний, інноваційний, організаційно-управлінський, фінансовий) як сукупність наявних ресурсів та компетенцій для досягнення стратегічних цілей енергозбереження.

Відтак, стратегія енергоефективності конкретних готельно-ресторанних комплексів повинна відповідати основним напрямам реалізації стратегії енергоефективності на державному рівні. Можна стверджувати, що на вибір стратегії енергоефективності впливають як внутрішні чинники підприємства (внутрішнє середовище, наявні ресурси і компетенції), так і стан зовнішнього середовища (макро- та мікрооточення). Базуючись на методології циклу постійного покращення «Плануй - Впроваджуй - Перевіряй - Дій» (Plan - Do - Check - Act, PDCA), що передбачена міжнародним стандартом ISO 50001:2011 «Energy management systems - Requirements with guidance for use», наведемо алгоритм розробки стратегії енергоефективності готельно-ресторанного підприємства (рис. 3).

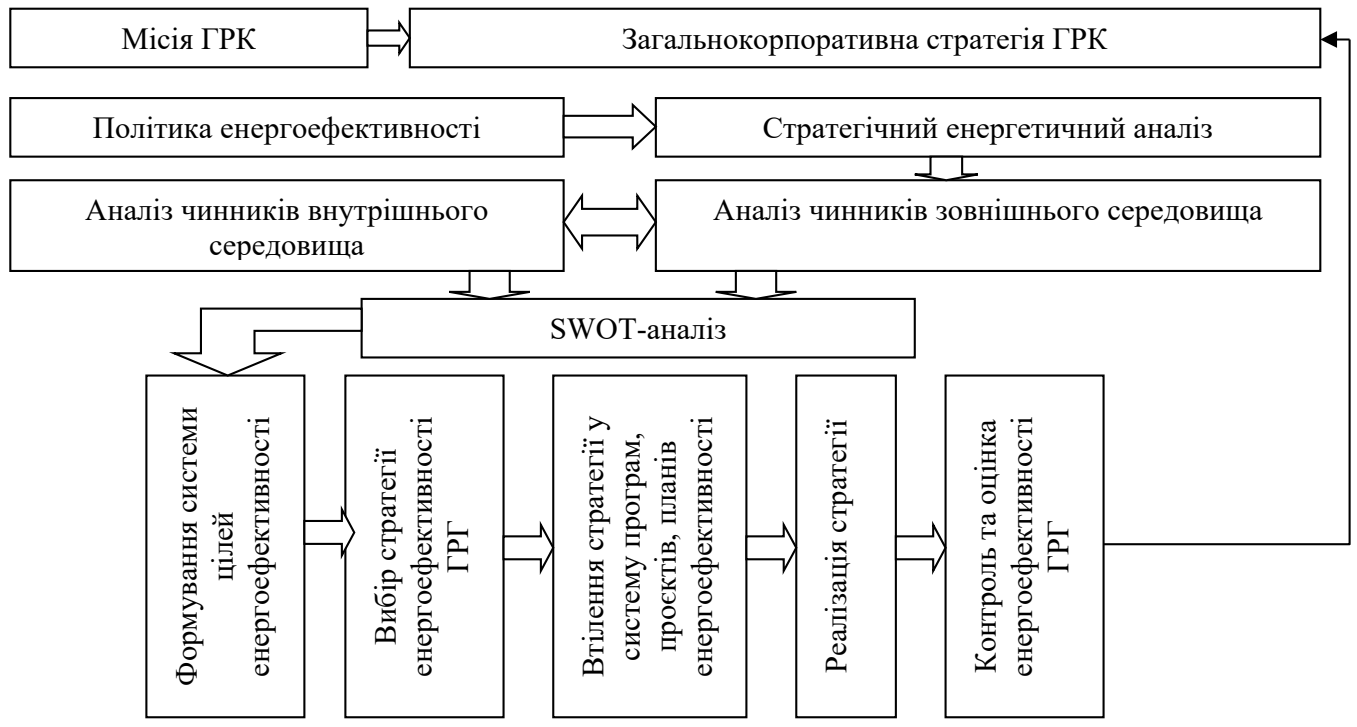

Puc. 3. Формування стратегії енергоефективності готельно-ресторанного комплексу

Fig. 3. Formation of energy efficiency strategy of hotel and restaurant complex

Враховуючи зазначене, зауважимо, що головна мета досягнення енергоефективності готельно-ресторанного комплексу - це забезпечення його стійкого і максимально ефективного функціонування, створення високого потен- 
ціалу розвитку i зростання в майбутньому. У цьому контексті у забезпеченні енергоефективності готельно-ресторанного комплексу вирішальне значеннямаєстратегічнеуправлінняякодинізсучаснихпідходівефективноїадаптації до мінливого зовнішнього середовища, попередження та нейтралізація небажаних ризиків і загроз, досягнення запланованих фінансових результатів і довгострокового успіху суб’єктів господарювання.

У конкретній соціально-економічній ситуації можна говорити про оптимізацію складу і вибору варіантів стратегії готельно-ресторанного комплексу. На основі цього переліку для кожного готельно-ресторанного комплексу має бути сформована, обговорена i прийнята власна, притаманна тільки йому комплексна стратегія, що враховує особливості макроекономічної ситуації, стан галузевого і регіонального оточення, його внутрішній потенціал, а також стратегію управління енергоефективністю.

Таким чином, стратегія управління енергоефективністю готельно-ресторанного комплексу в умовах нестабільного функціонування повинна містити складові, наведені на рис. 4.

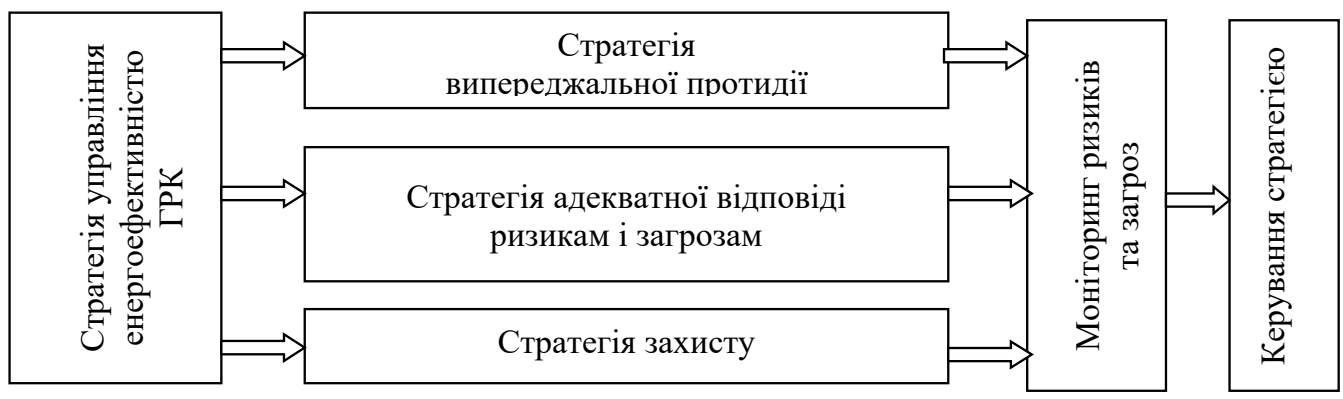

Puc. 4. Складові стратегії управління енергоефективністю готельно-ресторанного комплексу

Fig. 3. Components of energy efficiency management strategy of hotel and restaurant complex

Суть стратегії випереджальної протидії полягає в передбаченні та попередженні негативних явищ, підготовці до їхньої появи та недопущенні ще на початковому етапі. Дієвість стратегії може бути забезпечена завдяки енергостійкості підприємства сфери послуг, що допомагає упродовж певного часу виконувати свої функції навіть у разі виходу параметрів зовнішнього середовища за певні обмеження. Стратегія випереджальної протидії базується на заходах, які сприяють протидії кризовим явищам та уповільнюють процеси їх розвитку на підприємстві. До того ж підприємство здатне функціонувати, використовуючи такі властивості, як гнучкість і адаптивність, які дозволяють змінювати процеси, цілі та темпи їх досягнення або коригувати мету залежно від умов внутрішнього середовища.

Стратегія адекватної відповіді полягає у прийнятті керівництвом рішень, спрямованих на нейтралізацію зовнішніх і внутрішніх загроз, що постійно виникають на основі фінансового аналізу та зовнішнього середовища підприємства готельно-ресторанного господарства. У своїх діях стратегія адекватної відповіді 
опирається на резерви та додаткові ресурси підприємства, що стабілізують ситуацію, а також на компетентність дій керівництва у питаннях енергоефективності. Під час реалізації цієї стратегії визначаються шляхи успішного вирішення та подолання проблем, що дають готельно-ресторанному комплексу можливість виконувати свої виробничі завдання протягом певного часу за умови можливого кризового стану. Нераціонально організована система управління негативно позначається не тільки на усіх ланках виробничої діяльності підприємства, а також на відносинах із зовнішнім середовищем, що, зі свого боку, впливає на енергоекономічні показники.

\section{Висновки та обговорення результатів}

На сучасному етапі розвитку готельно-ресторанні комплекси визначають власну економічну політику, формують портфель замовлень та несуть відповідальність за результати господарської діяльності. Усі перераховані процеси актуалізують проблему управління енергоефективністю. Управління енергоефективністю готельно-ресторанного комплексу забезпечує результативність його діяльності в цілому у поточному періоді функціонування та в довгостроковій перспективі. При цьому ефективне управління може здійснюватися лише за умови формування цілісної системи, яка призначена для вирішення основних його завдань. Основними передумовами забезпечення енергоефективності є визначення стратегії енергоефективності та тактичних заходів її реалізації, відстеження зовнішніх і внутрішніх загроз в енергоефективній сфері.

Таким чином, розробка стратегії управління енергоефективністю готельноресторанного комплексу сприятиме вчасному діагностуванню та розподілу об'єктивних і суб’єктивних негативних дій; визначенню переліку заходів із запобігання загрозам енергоефективності; оцінці ефективності планованих заходів з огляду нейтралізації негативних дій; оцінці запропонованих заходів щодо усунення загроз.

Перспективою подальших досліджень є практичне впровадження запропонованої стратегії та механізму формування системи управління енергоефективністю готельно-ресторанного комплексу.

\section{СПИСОК БІБЛІОГРАФІЧНИХ ПОСИЛАНЬ}

Амоша, А. И., Федоренко, В. Г., \& Белопольский, Н. Г. (2008). Экономические подходы к эффективному использованию энергетических ресурсов. Економіка та держава, 1, 4-7.

Барановська, С. В., Ружицький, А. А., \& Михайлович, Ю. В. (2019). Роль сфери послуг в економіці України. В Актуальні задачі сучасних технологій, VIII Міжнародна науково-технічна конференція молодих учених та студентів (с. 105-106), Тернопіль, Україна. Тернопільський національний технічний університет ім. І. Пулюя.

Берзіна, С. В., Берзін, В. М., Вакараш, В. М., Ворфоломеєв, А.В., Горопацький, В. Г., Дюжилова, Н. О., Картавцев, О. М., Перминова, С. Ю., Ткач, О. В., \& Яреськовська, І. І. (2017). Системи екологічного управління: сучасні тенденції та міжнародні стандарти. Інститут екологічного управління та збалансованого природокористування.

Бобров, Є. А. (2013). Енергетична безпека держави [Монографія]. Університет економіки та права «КРОК». 
Валінкевич, Н. В. (2018). Управління енергозбереженням підприємств в контексті організаційно-економічної модернізації. В Стратегічні альтернативи економічного розвитку підприємницької діяльності [Монографія] (с. 243-252). Житомирський державний технологічний університет.

Варналій, 3. С., Буркальцева, Д. Д., \& Саєнко, О. С. (2011). Економічна безпека України: проблеми та пріоритети зміцнення [Монографія]. Знання України.

Галасюк, С. С., \& Шикіна, О. В. (2015). Організаційно-економічні засади функціонування малих готелів [Монографія]. Атлант.

Геєць, В. М., Кизим, М. О., \& Клебанова, Т. С. (2006). Моделювання економічної безпеки: держава, регіон, підприємство [Монографія]. ВД «ІНЖЕК».

Єрмаченко, В. Є., \& Журавльова, С. М. (2015). Стратегії розвитку підприємств готельного господарства. Молодий вчений, 5(1), 138-141.

Завідна, Л. Д. (2017). Готельний бізнес: стратегії розвитку [Монографія]. Київський національний торговельно-економічний університет.

Кузнєцова, Н. М., \& Нездоймінов, С. Г. (2010). Регіональний вимір розвитку туристичного та готельного бізнесу [Монографія]. Астропринт.

Кузьмін, О. Є., Подольчак, Н. Ю., \& Матвіїшин, В. Є. (2011). Управління та зниження рівня ризиків енергозабезпечення підприємств [Монографія]. Міські інформаційні системи.

Ляшук, М., \& Єрко, І. (2020). Сучасні тенденції розвитку готельно-ресторанного бізнесу рекреаційного району. Ресторанний і готельний консалтинг. Інновації, 3(1), 109-119. https://doi.org/10.31866/2616-7468.3.1.2020.205574

Миколюк, О. А. (2019). Управління енергетичною безпекою підприємств: теорія, методологія, практика [Монографія]. Хмельницький національний університет.

Парфіненко, А. Ю. (Ред.). (2017) Сучасні тенденції розвитку готельно-ресторанного бізнесу: міжнародний та національний досвід [Монографія]. Харківський національний університет імені В. Н. Каразіна.

Рижик, І. О., Глєбова, А. О., \& Синягівська, В. С. (2020). Особливості формування моделі управління бізнес-процесами підприємства сфери послуг. Східна Європа: економіка, бізнес та управління, 1(24), 152-160.

Романів, О. Я., Трусова, Т. С., \& Бричка, Р. П. (2015). Розвиток готельного господарства у ринкових умовах. Вісник Національного університету «Львівська політехніка». Менеджмент та підприємництво в Україні: етапи становлення і проблеми розвитку, $819,427-433$.

Ряшко, Г. М., Крусір, Г. В., \& Новічкова, Т. П. (2016). Аналіз енергозберігаючих технологій в ресторанному господарстві. Наукові праці [Одеської національної академії харчових технологій], 80(2), 17-21.

Соколова, В. І., Крусір, Г. В., Шпирко, Т. В., Кузнєцова, І. О., \& Коваленко, І. В. (2019). Розробка ключових елементів системи ресурсо- та енергоефективності. Наукові праці [Одеської національної академії харчових технологій], 83(1), 21-26.

Wong, IpKin A., Ruan, W. J., Cai, X., \& Huang, GuoQiong I. (2021). Green-Induced tourist equity: the cross-level effect of regional environmental performance. Journal of Sustainable Tourism, 29(7), 1043-1062.

World Economic Forum. (2017, 5 April). The Travel \& Tourism Competitiveness Report 2017.https:// www.weforum.org/reports/the-travel-tourism-competitiveness-report-2017

\section{REFERENCES}

Amosha, A. I., Fedorenko, V. G., \& Belopolskii, N. G. (2008). Ekonomicheskie podkhody k effektivnomu ispol'zovaniyu energeticheskikh resursov [Economic approaches to the efficient use of energy resources]. Ekonomika ta Derzhava, 1, 4-7 [in Russian]. 
Baranovska, S. V., Ruzhytskyi, A. A., \& Mykhailovych, Yu. V. (2019). Rol sfery posluh v ekonomitsi Ukrainy [The role of services in the economy of Ukraine]. In Aktualni zadachi suchasnykh tekhnolohii [Current issues of modern technologies], VIII International Scientific and Technical Conference of Young Scientists and Students (pp. 105-106), Ternopil, Ukraine. Ternopil Ivan Puluj National Technical University [in Ukrainian].

Berzina, S. V., Berzin, V. M., Vakarash, V. M., Vorfolomeiev, A .V., Horopatskyi, V. H., Diuzhylova, N. O., Kartavtsev, O. M., Permynova, S. Yu., Tkach, O. V., \& Yareskovska, I. I. (2017). Systemy ekolohichnoho upravlinnia: suchasni tendentsii ta mizhnarodni standarty [Environmental management systems: current trends and international standards]. Institute of Environmental Management and Sustainable Nature Management [in Ukrainian].

Bobrov, Ye. A. (2013). Enerhetychna bezpeka derzhavy [Energy security of the state] [Monograph]. "KROK" University [in Ukrainian].

Halasiuk, S. S., \& Shykina, O. V. (2015). Orhanizatsiino-ekonomichni zasady funktsionuvannia malykh hoteliv [Organizational and Economic Principles of Operation of Small Hotels] [Monograph]. Atlant [in Ukrainian].

Heiets, V. M., Kyzym, M. O., \& Klebanova, T. S. (2006). Modeliuvannia ekonomichnoi bezpeky: derzhava, rehion, pidpryiemstvo [Modeling of Economic Security: State, Region, Enterprise] [Monograph]. VD "INZhEK" [in Ukrainian].

Kuzmin, O. Ye., Podolchak, N. Yu., \& Matviishyn, V. Ye. (2011). Upravlinnia ta znyzhennia rivnia ryzykiv enerhozabezpechennia pidpryiemstv [Management and Reduction of Energy Supply Risks of Enterprises] [Monograph]. Miski informatsiini systemy [in Ukrainian].

Kuznietsova, N. M., \& Nezdoiminov, S. H. (2010). Rehionalnyi vymir rozvytku turystychnoho ta hotelnoho biznesu [Regional Dimension of Tourism and Hotel Business Development] [Monograph]. Astroprynt [in Ukrainian].

Liashuk, M., \& Yerko, I. (2020). Suchasni tendentsii rozvytku hotelno-restorannoho biznesu rekreatsiinoho raionu [Modern Trends of Development of Hotel and Restaurant Business of the Recreation District]. Restaurant and Hotel Consulting. Innovations, 3(1), 109-119. https://doi.org/10.31866/2616-7468.3.1.2020.205574 [in Ukrainian].

Mykoliuk, O. A. (2019). Upravlinnia enerhetychnoiu bezpekoiu pidpryiemstv: teoriia, metodolohiia, praktyka [Energy Security Management of Enterprises: Theory, Methodology, Practice] [Monograph]. Khmelnytskyi National University [in Ukrainian].

Parfinenko, A. Yu. (Ed.). (2017) Suchasni tendentsii rozvytku hotelno-restorannoho biznesu: mizhnarodnyi ta natsionalnyi dosvid [Current Trends in the Hotel and Restaurant Business: International and National Experience] [Monograph]. V.N. Karazin Kharkiv National University [in Ukrainian].

Riashko, H. M., Krusir, H. V., \& Novichkova, T. P. (2016). Analiz enerhozberihaiuchykh tekhnolohii $\mathrm{v}$ restorannomu hospodarstvi [Analysis of energy-saving technologies in the restaurant industry]. Scientific works [Odessa National Academy of Food Technologies], 80(2), 17-21 [in Ukrainian].

Romaniv, O. Ya., Trusova, T. S., \& Brychka, R. P. (2015). Rozvytok hotelnoho hospodarstva u rynkovykh umovakh [Development of the hotel industry in market conditions]. Bulletin of Lviv Polytechnic the National University. Management and Entrepreneurship in Ukraine: Stages of Formation and Problems of Development, 819, 427-433 [in Ukrainian].

Ryzhyk, I. O., Hliebova, A. O., \& Syniahivska, V. S. (2020). Osoblyvosti formuvannia modeli upravlinnia biznes-protsesamy pidpryiemstva sfery posluh [Features of formation of model of management of business processes of the enterprise of sphere of services]. Eastern Europe: Economy, Business and Management, 1(24), 152-160 [in Ukrainian].

Sokolova, V. I., Krusir, H. V., Shpyrko, T. V., Kuznietsova, I. O., \& Kovalenko, I. V. (2019). Rozrobka kliuchovykh elementiv systemy resurso- ta enerhoefektyvnosti [Development of key elements of the resource and energyefficiency system]. Scientific Works [Odessa National Academy of Food Technologies], 83(1), 21-26 [in Ukrainian].

Valinkevych, N. V. (2018). Upravlinnia enerhozberezhenniam pidpryiemstv v konteksti orhanizatsiino-ekonomichnoi modernizatsii [Energy saving management of enterprises in the 
context of organizational and economic modernization]. In Stratehichni alternatyvy ekonomichnoho rozvytku pidpryiemnytskoi diialnosti [Strategic Alternatives of Economic Development of Entrepreneurial Activity] [Monograph] (pp. 243-252). Zhytomyrskyi derzhavnyi tekhnolohichnyi universytet [in Ukrainian].

Varnalii, Z. S., Burkaltseva, D. D., \& Saienko, O. S. (2011). Ekonomichna bezpeka Ukrainy: problemy ta priorytety zmitsnennia [Economic Security of Ukraine: Problems and Priorities of Strengthening] [Monograph]. Znannia Ukrainy [in Ukrainian].

Wong, IpKin A., Ruan, W. J., Cai, X., \& Huang, GuoQiong I. (2021). Green-Induced tourist equity: the cross-level effect of regional environmental performance. Journal of Sustainable Tourism, 29(7), 1043-1062 [in English].

World Economic Forum. (2017, 5 April). The Travel \& Tourism Competitiveness Report 2017. https://www.weforum.org/reports/the-travel-tourism-competitiveness-report-2017 [in English].

Yermachenko, V. Ye., \& Zhuravlova, S. M. (2015). Stratehii rozvytku pidpryiemstv hotelnoho hospodarstva [Strategies for the development of hotel enterprises]. Molodyi Vchenyi, 5(1), 138-141 [in Ukrainian].

Zavidna, L. D. (2017). Hotelnyi biznes: stratehii rozvytku [Hotel Business: Development Strategies] [Monograph]. Kyiv National University of Trade and Economics [in Ukrainian].

Стаття надійшла до редакції 18.04.2021 р. 
УДК 640.4:005.2]:[005.61:658.261

Оксана Миколюк,

доктор экономических наук, доцент,

Хмельницкий национальный университет

Хмельницкий, Украина,

oksanamik81@gmail.com

https://orcid.org/0000-0001-8526-0829

\section{УПРАВЛЕНИЕ ГОСТИНИЧНО-РЕСТОРАННЫМ КОМПЛЕКСОМ НА ОСНОВЕ ЭНЕРГОЭФФЕКТИВНОСТИ}

Актуальность. Устойчивое развитие предприятий гостинично-ресторанного хозяйства невозможно без надежного, стабильного, обоснованного обеспечения энергетическими ресурсами. Рациональное и экономное потребление энергетических ресурсов определяет энергоэффективность их функционирования и играет ведущую роль в обеспечении экономического роста отечественных предприятий сферы услуг. Приоритетом в развитии предприятий сферы гостеприимства все чаще становятся стабильное функционирование и рост экономического потенциала в условиях рыночных отношений, которые главным образом зависят от наличия системы энергоэффективности. Предметом исследования является формирование стратегии энергоэффективности, что будет способствовать координации действий высшего менеджмента в решении проблем обеспечения энергоэффективного функционирования гостинично-ресторанного комплекса. Цель исследования заключается в теоретико-методологическом обосновании значения и места системы энергоэффективности в системе стратегического управления гостинично-ресторанным комплексом. Методы исследования: монографический анализ, абстрагирование и морфологический анализ, группировки и классификации. Главные результаты и выводы. В результате исследования раскрыты сущность и последовательность этапов управления энергоэффективностью гостинично-ресторанным комплексом. Сформированы взаимосвязи стратегии энергоэффективности гостинично-ресторанного комплекса и механизма ее управления. Предложен алгоритм разработки стратегии энергоэффективности гостинично-ресторанного комплекса и обоснованы его составляющие.

Ключевые слова: управление, гостинично-ресторанный комплекс, энергоэффективность, стратегия энергоэффективности. 
UDC 640.4:005.2]:[005.61:658.261

\author{
Oksana Mykoliuk, \\ Doctor of Economics, \\ Khmelnytskyi National University \\ Khmelnytskyi, Ukraine, \\ oksanamik81@gmail.com \\ https://orcid.org/0000-0001-8526-0829
}

\title{
MANAGEMENT OF HOTEL AND RESTAURANT COMPLEX ON THE BASIS OF ENERGY EFFICIENCY
}

Topicality. Sustainable development of hotel and restaurant industry appears to be not possible without a reliable, stable, reasonable provision of energy resources. Rational and economical consumption of energy resources determines energy efficiency of their operation, and plays a leading role in ensuring the economic growth of blighty enterprises in the service sector. Stable functioning and growth of the economic potential in market relations conditions are constantly becoming the priority in the development of hospitality sphere enterprises. They mainly depend on the availability of energy efficiency. The subject of this study is the formation of the energy efficiency strategy, that will support the coordination of the senior management actions in solving some problems of the energy efficiency providing the hotel and restaurant complex operation. The purpose of this research lies in theoretical and methodological substantiation of the importance and place of the energy efficiency system in strategic management of the hotel and restaurant complex. Research methods: monographic analysis, abstraction and morphological analysis, groups and classifications. Main results and conclusions. According to the obtained research results, the essence and sequence of the stages of energy efficiency management in hotel and restaurant complex are defined. The correlations between the energy efficiency strategy of the hotel and restaurant complex, and the mechanism of its management are formed. The algorithm of energy efficiency strategy elaboration in the hotel and restaurant complex is offered, as well as its components are substantiated.

Keywords: management, hotel and restaurant complex, energy efficiency, energy efficiency strategy. 